\title{
A Review on Knock Phenomena in CNG-Diesel Dual Fuel System
}

\author{
Fathul Hakim Zulkifli ${ }^{a}$, Mas Fawzi ${ }^{\mathrm{b} *}$, and Shahrul Azmir Osman ${ }^{\mathrm{c}}$ \\ Automotive Research Group, Center for Energy and Industrial Environmental Studies, \\ Faculty of Mechanical and Manufacturing Engineering, Universiti Tun Hussein Onn Malaysia, \\ 86400 Parit Raja, Batu Pahat, Johor, Malaysia.
}

afathul@uthm.edu.my, bfawzi@uthm.edu.my*, 'shahrula@uthm.edu.my

\section{Keywords: Knock, Dual fuel, CNG-Diesel}

\begin{abstract}
The compressed natural gas $(\mathrm{CNG})$ - diesel dual fuel engine is discussed through their basic operation and its characteristic. The main problem of running a diesel engine on dual fuel mode with CNG as main fuel is addressed. A brief review of knock phenomena which is widely associated with a dual fuel engine is also covered. Methods to suppress onset knock were suggested.
\end{abstract}

\section{Introduction}

Recent climate change due to global warming have led us to search for sustainable energy sources with the lowest possible greenhouse-gas emissions. Natural gas is not a renewable fuel but it has abundant resources and the lowest average specific carbon dioxide emission among the nonrenewable fossil fuel energy resources [1]. Natural gas is odorless, colorless, and tasteless in its pure form. It consists mostly of methane $\left(\mathrm{CH}_{4}\right)$. As of January 2009, World Proved Reserves of Oil and Natural Gas stated that world natural gas reserved has the capacity of 6,342 trillion cubic feet, while oil reserved has the capacity of 1,342 billion barrels [2,3].

The Malaysian National Green Technology Policy was launched by the Prime Minister of Malaysia on 24 July 2009. The policy aims to minimize the degradation of the environment while conserving the use of energy and natural resources [4]. The target is to reduce $40 \%$ of carbon equivalent emission by the year 2020. Recently, National Automotive Policy (NAP 2014) was launched in January 2014 with a vision of transforming the competitiveness of the Malaysian automotive industry to face the global challenges. NAP 2014 objective is to develop Malaysia as the regional automotive hub in energy efficient vehicles (EEV) [5].

Most shipping and logistics companies, particularly in Malaysia, uses diesel fuel in their medium-duty, heavy-duty engines and prime mover vehicles. All these vehicles partly contribute to the pollution of our green environment. Alternatively, the exhaust emission from using compressed natural gas (CNG) fuel is environmentally friendly compared to diesel. A study done by Battelle, NREL and West Virginia University is using modified diesel trucks to CNG showed significant improvements in exhaust emission. CNG engines produce $25 \%$ lower carbon monoxide, $49 \%$ lower nitrogen oxides and up to $95 \%$ lower particulate matter compared to the standard diesel engine [6]. With CNG combustion, such emissions are inherently reduced relative to diesel fueled engines due to the nature of the combustion and the molecular makeup of the fuel [7].

The cost of CNG fuel and CNG engine maintenance is also more economical compared to diesel. In Malaysia, after subsidized as of July 2014, the cost of CNG is RM0.62/liter while the cost of diesel is RM2.00/liter. Due to the awareness and long term benefit of green technology and sustainability of using CNG fuel, many companies have started to modify their diesel vehicles to either dual fuel CNG-diesel vehicles, or mono fuel CNG vehicles.

\section{CNG-Diesel Dual Fuel System}

A dual fuel engine uses two types of fuel. In the case of CNG-diesel system, the main fuel is CNG. Small quantity of diesel, commonly known as pilot fuel, is used as the ignition source in high compression CNG-air mixture environment. An overview of the dual fuel operation is shown in 
Figure 1. The CNG fuel can be supplied either using a mixer, port fuel injection, or in-cylinder direct injection. The advantages of using a dual fuel system are [8,9]:

1. The engine can operate interchangeably on CNG with diesel pilot, or on $100 \%$ diesel. It is highly useful when the supply of CNG is not available in certain area.

2. Most existing diesel engines can be converted to dual fuel operation with lower cost and time than converting to a spark ignition engine for monogas system.

\section{Dual Fuel Operation}

- Natural gas mixed with air in intake system

- Pilot diesel act as ignition source

- Diesel start up, power density and transient performance

- Gas substitutes rate up to $70 \%$

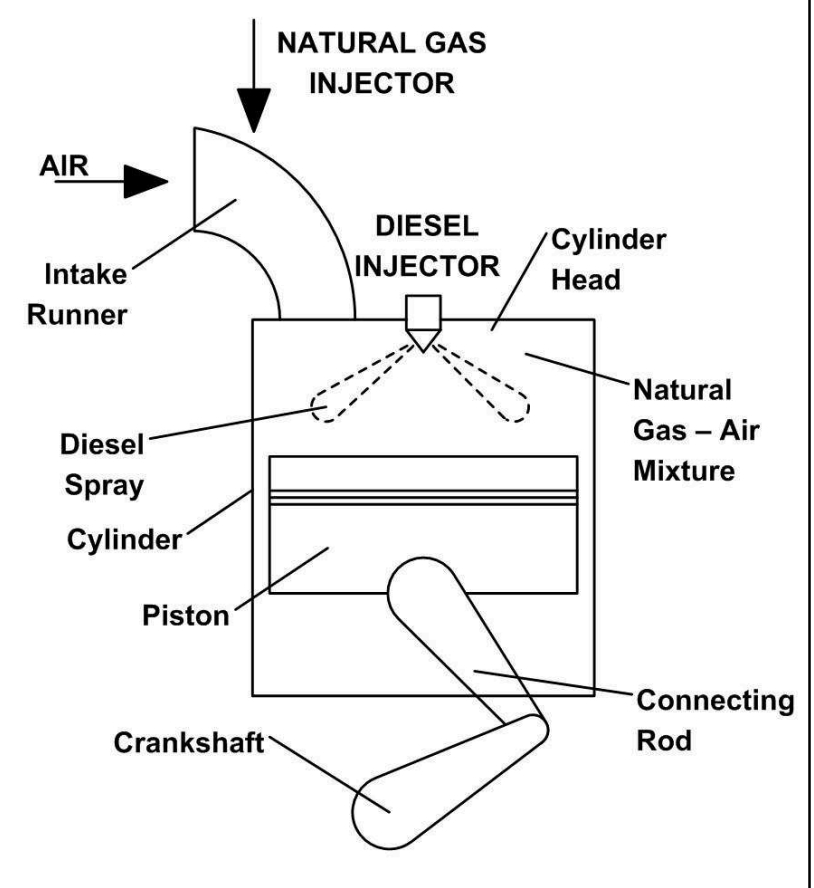

Figure 1 An overview of dual fuel operation

However, dual fuel engines showed poor brake power, poor combustion efficiency, and high unburned hydrocarbon and carbon monoxide emission at low load operations [10-12]. This is mainly because of low load operations, lean CNG combustion is practiced. The result in this low load condition shows a high amount of hydrocarbon emission, and the engine performance is affected by the time interval between fuel injection timing and ignition timing.

A well-known problem in lean-burn CNG engines is poor ignitability [13-15]. The ignitability of the first flame core relies on local fuel-air mixture concentration near the ignition position. The local equivalence ratio surrounding the flame core should be near to stoichiometries. Too rich or too lean local mixture will cause the first flame core to quench before it begins to propagate to other parts of the combustion chamber. With a lean air-fuel mixture, longer time is required for the initial flame core and rapid flame to develop. Slow flame propagation causes poor combustion stability and intermittently producing misfires [16-18]. In all cases, unstable combustion can be observed. Particularly when the fuel injection timing is near to ignition timing, cycle -to-cycle combustion variation becomes higher and some misfires can be observed.

A typical ratio of a dual fuel engine is $70 \% \mathrm{CNG}$ and $30 \%$ diesel. The ignitability of this mixture proportion can easily be achieved without major modification of the stock diesel engine, and using the default mixture preparation method. In the dual combustion mode, it may be possible to obtain a diesel substitution rate up to a maximum of $90 \%$ and $70 \%$ on average, as the actual work indicates [19]. A study by Lim et al. has shown that the CNG alternation rate may achieve over $89 \%$ in all operating ranges of $\mathrm{CNG}$-diesel dual-fuel engine. At this time, the amount of $\mathrm{CO}_{2}$ (Carbon Dioxide) and PM (particulate matter) are decreased while CO (carbon monoxide), NOx (nitrogen oxide), and HC (hydrocarbon) are increased [20]. 


\section{Knock Phenomena}

The research into the knock phenomenon for dual fuel engine has been carried out over the years. Knock is due to an autoignition phenomenon dominated by chemical kinetic reactions of the premixed fuel-air system. Karim et al. [21] stated that the occurrence of knock was confined by a relatively weak mixture around $60-80 \%$ of the stoichiometric ratio. Their investigation into the effects of changes in various operating parameters such as intake temperature and the quantity and quality of pilot liquid fuel, while using various primary gaseous fuels (propane, methane and hydrogen) has proven that knock was observed mainly caused by autoignition of the gaseous fuelair mixture in the neighbourhood of the ignition points originating from the small pilot liquid fuel sprays. For CNG-diesel dual fuel operation, the knock phenomena are widely associated with CNGdiesel combustion due to high pressure-rise rates with the auto-ignition of fuel during the premixed combustion stage. In part load cases, $\mathrm{CNG}$-diesel combustion increase ignition delay time, reduce the burning rate and combustion duration compared to diesel [22]. These problems allow more time for flame propagation that resulting tendency to knock. Wannatong et al. [23] found that intake mixture temperature and amount of CNG supply plays important role in knock characteristic. The real case situation also been reported that dual fuel mode could cause an engine damage due to knock phenomenon [24]. Selim [25] claimed that the onset knock for dual fuel engine associated with a drop in thermal efficiency and output power. He also found that knock starts earlier when high compression ratio is used.

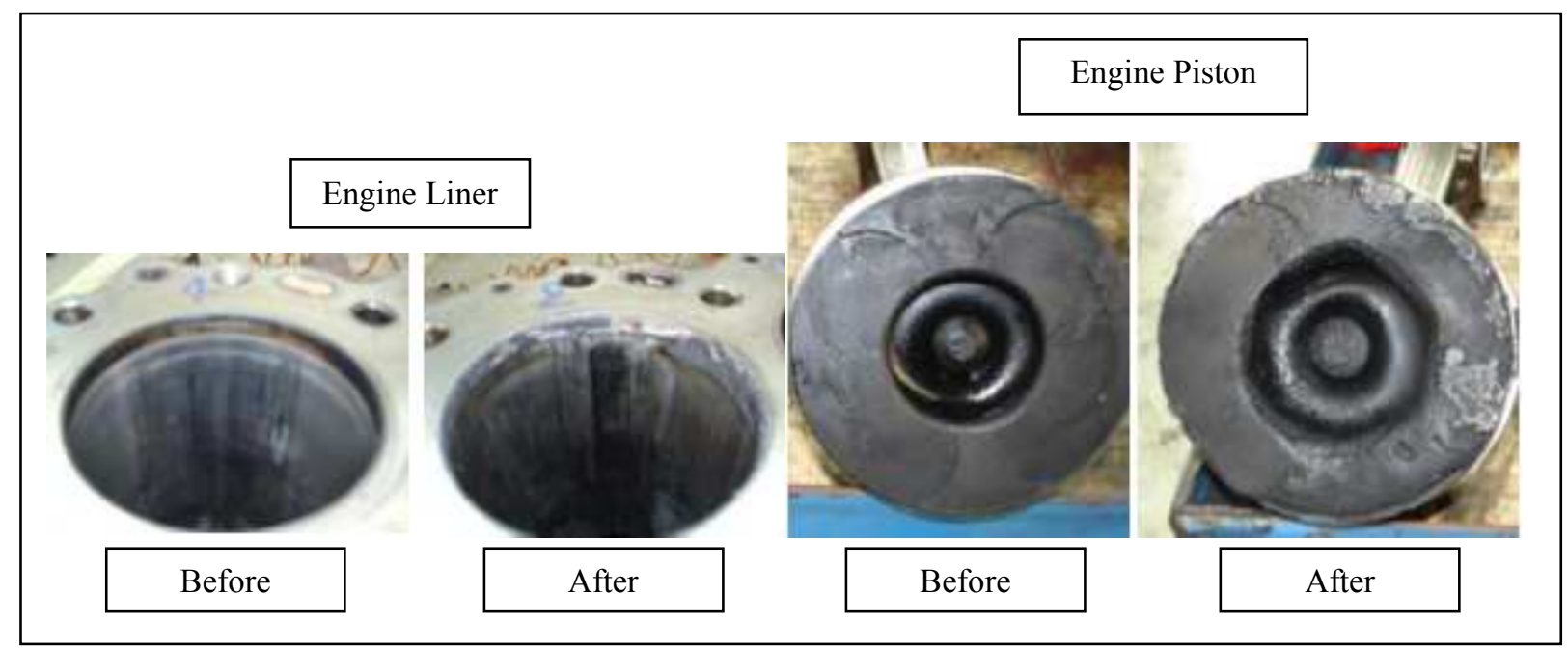

Figure 2 Damaged engine liner and piston due to dual fuel knocking [23]

However, Abdelaal et al. [26] found that oxygen enrichment in engine cylinder has potential to reduce knock onset. Their work showed that adding oxygen content in the combustion chamber reduces $\mathrm{CO}$ and $\mathrm{HC}$ emissions and essentially drop smoke levels for diesel pilot.

From these reports [21-26] the cause knock phenomena are still an open subject, especially with the current technology advancement that provides ways to measure or simulates such occurrence. CNG is a high octane fuel, which has the characteristic of resisting low temperature ignition normally associated with knock phenomena. $\mathrm{CNG}$ has an auto ignition temperature of $580^{\circ} \mathrm{C}$, while diesel has an auto ignition temperature of $210^{\circ} \mathrm{C}$. Theoretically, the increase in ignition delay time and slower fuel burning rate alone has little effect on the knock occurrence.

\section{Knock Suppression Methods}

Several studies have been carried out to suppress knock on a compression ignition engine. One of the methods is by adding water into the combustion chamber during knocking [27]. Water is a very good diluent. It evaporates by absorbing heat in the combustion chamber and keep the mixture below its self ignition temperature. This method was able to restore the performance during full 
load while maintaining fuel quantity, however, HC emission slightly increased. Another work suggested that prevention of knock onset is possible by implementing optimal fueling strategies [28]. For low equivalent ratios, some amount of pilot fuel is required to improve thermal efficiency and exhaust emissions, while on high equivalent ratios, small amount of pilot fuel with a moderate injection rate is effective for preventing knocking. Another commonly used method to reduce exhaust temperature and limit knock is by using excessive fuel to decrease the combustion temperature. This fuel enrichment method will increase $\mathrm{HC}$ and $\mathrm{CO}$ emissions. However, using exhaust gas recirculation (EGR) as diluents allowed the use of overall stoichiometric composition of the charge, thus ensures a good conversion of all emissions. A cool EGR can also be used to limit exhaust gas temperature and inhibit knock [29-32].

\section{Conclusions}

From this brief review, CNG has a huge potential to be utilized in a dual fuel engine system which pilot diesel act as an ignition source in compression ignition engine. Problems associated with CNG-Diesel dual fuel engine has been addressed in the literature. However, knock phenomena still happens in CNG-diesel dual fuel engine, despite many research on such matters. More work needs to be done in finding the root cause of the knock occurrence and to ensure the effectiveness of actions taken to remedy the knock phenomena.

\section{Acknowledgement}

The authors duly acknowledge the Universiti Tun Hussein Onn Malaysia for the financial support under the Short Term Grant scheme vot.1290.

\section{References}

[1] W. Moomaw, F. Yamba, M. Kamimoto, L. Maurice, J. Nyboer, K. Urama, and T. Weir, "Introduction," in IPCC Special Report on Renewable Energy Sources and Climate Change Mitigation, O. Edenhofer, R. Pichs-Madruga, Y. Sokona, K. Seyboth, P. Matschoss, S. Kadner, T. Zwickel, P. Eickemeier, G. Hansen, S. Schlömer, and C. v. Stechow, Eds.: Cambridge University Press, 2011.

[2] P. Corporation, "Worldwide Look at Reserves and Production," Oil \& Gas, vol. 106, 48, pp. 2223, 2008.

[3] EIA, "International Energy Module," US Energy Information Administration, DOE/EIA0554(2010), 2010.

[4] KeTTHA, "The National Green Technology Policy", 2009.

[5] Malaysia Automotive Institute, "Malaysia Automotive Technology Roadmap Highlight", 2014.

[6] K. Chandler, K. Walkowicz, and N. Clark, "United Parcel Service (UPS) CNG Truck Fleet: Final Results," US Department of Energy, 2002.

[7] M. Dahodwala, S. Joshi, E. Koehler, M. Franke, "Investigation of Diesel and CNG Combustion in a Dual Fuel Regime and as an Enabler to Achieve RCCI Combustion," SAE Technical Paper 2014-011308, 2014.

[8] C. S. Weaver and S. H. Tuner, "Dual fuel natural gas / diesel engines: Technology, performance and emission", SAE Paper No. 940548, 1994.

[9] N. Ahmad, M. K. G. Babu, and A. Ramesh, "Experimental Investigations of different parameters affecting the performance of a CNG-diesel dual fuel engine", SAE Paper No. 2005-013767, 2005.

[10] T. Aroonsrisopon, M. Salad, E. Wirojsakunchai, K. Wannatong, S. Siangsanorh, and N. Akarapanjavit, "Injection strategies for operational improvement of diesel dual fuel engines under low load conditions", SAE Paper No. 2009-011855, 2009.

[11] G. A. Karim, "Combustion in gas fueled compression ignition engines of dual fuel type", Journal of Engineering for Gas Turbine and Power, Vol. 125, pp. 827-836, 2003. 
[12] G. H. Abd Alla, H. A. Soliman, O. A. Badr, and M. F. Abd Rabbo, "Effect of injection timing on the performance of a dual fuel engine", Energy Conversion and Management, 43, pp. 269-277, 2002.

[13] M. F. M. Ali, Y. Kidoguchi, Y. Oka, and T. Kaida, "Improvement of Combustion of CNG Engine using CNG Direct Injection and Gas-jet Ignition Method", JSAE PF \& L, Aug 2011, Kyoto, JSAE 20119132, 2011.

[14] Y. Kidoguchi, S. Masaaki, U. Hiromitsu, and K. Miwa, "A Fundamental Study on Improvement of Ignitability and Combustion Stability of CNG Jet (in Japanese)," Trans. of JSAE, vol. 36, 1, pp. 15-20, 2005.

[15] Y. Goto, "Mixture Formation and Ignition in a Direct Injection Natural Gas Engine," JSME Int J Ser B (Jpn Soc Mech Eng), vol. 42, 2, pp. 268-274, 1999.

[16] D. S. K. Ting and M. D. Checkel, "The effects of turbulence on spark-ignited, ultra lean, premixed methane-air flame growth in a combustion chamber," SAE Technical Paper, 952410, 1995.

[17] A. Das and H. C. Watson, "Development of a natural gas spark ignition engine for optimum performance," Proc Inst Mech Eng, Part D: J. Automobil Engineering, vol. 211, 36, pp. 61-78, 1997.

[18] M. F. M. Ali, T. Kaida, Y. Ido, Y. Nada, and Y. Kidoguchi, Flame Development and THC of CNG with Hydrogen Addition using Gas-jet Ignition with Two-stage Injection. COMODIA 2012, 24 - 26 July, Recent Hotel, Fukuoka, Japan, 2012.

[19] C. Doppelbauer, Mario Penz, Daniel Renner, Karl Masser, F. Dorfer, "DUAL FUEL Potential of Combined Combustion of CNG and Diesel Fuel," SAE Technical Paper 2013-36-0133, 2013.

[20] Lim, O., Iida, N., Cho, G., and Narankhuu, J., "The Research about Engine Optimization and Emission Characteristic of Dual Fuel Engine Fueled with Natural Gas and Diesel," SAE Technical Paper 2012-32-0008, 2012.

[21] G. A. Karim, S. R. Klat and N. P. W. Moore, "Knock in dual fuel engines", Proc. Inst. Mech. Engr, vol. 181, pp. 453-466, 1967.

[22] Liu Z, Karim GA., "An examination of the ignition delay period in gas-fueled diesel engine with EGR”, Trans AMSE J Eng Gas Turbines Power, vol. 120, pp. 225-231, 1998.

[23] K. Wannatong, N. Akarapanyavit, S. Siengsanorh and S. Chanchaona, "Combustion and knock characteristics of natural gas diesel dual fuel engine”, JSAE 20077147, SAE 2007-01-2047, 2007.

[24] Nwafor OMI., "Knock characteristics of dual-fuel combustion in diesel engines using natural gas as primary fuel", Sadhana, vol.27, 27, pp. 375-382, 2002.

[25] M. Y. E. Selim, "Sensitivity of duel fuel engine combustion and knocking limits to gaseous fuel composition", Energy Conversion and Management, Vol 45, pp. 411-425, 2004.

[26] M. M. Abdelaal, B. A. Rabee, A. H. Hegab, "Effect of adding oxygen to the intake air on a dual-fuel engine performance, emissions, and knock tendency”, Energy, Vol 61, pp. 612-620, 2013.

[27] R. Karthikeyan and N. V. Mahalakshmi, "Performance and emission characteristics of turpentine-diesel dual fuel engine and knock suppression using water diluents", International Journal of Energy Research, Vol 31, pp 960-974, 2007.

[28] T. Ishiyama, M. Shioji, S. Mitani, H. Shibata and M. Ikegami, "Improvement of Performance and Exhaust Emissions in a Converted Dual Fuel Natural Gas Engine", SAE Technical Paper 200001-1866, 2000.

[29] P. Sebastian, L. Philippe, L. Samuel, M. Stephanie, T. Eva, "Cooled EGR for a turbo SI engine to reduce knocking and fuel consumption", SAE paper 2007-01-3978, 2007.

[30] G. Borje, A. Hans-Erik, S. Per, O. Eric, "Knock suppression in turbocharged SI engine by using cooled EGR”, SAE Paper 982476, 1998.

[31] G. Borje, A. Hans-Eric, "Replacing fuel enrichment in a turbo charged SI engine: lean burn or cooled EGR", SAE paper 1999-01-3505, 1999.

[32] A. Helmatel and I. Denbratt, "HCCI Operation of a Passenger Car Common Rail DI Diesel Engine With Early Injection of Conventional Diesel Fuel”, SAE Paper 2004-01-0935, 2004. 